\title{
Foreign experience of legal regulation of medical and social expertise (on the example of the Republic of Belarus)
}

\author{
Aleksei Raylyan Financial \\ University under the Government \\ of the Russian Federation \\ Moscow, Russia \\ candidate of legal sciences, \\ associate professor of the \\ Department of legal regulation of \\ economic activities of the \\ Financial University under the \\ Government of the Russian \\ Federation. \\ skink@rambler.ru
}

\author{
Oksana Petyukova Financial \\ University under the Government \\ of the Russian Federation \\ Moscow, Russia \\ doctor of legal sciences, deputy \\ dean of the Law faculty for \\ science research and international \\ cooperation, professor of the \\ Department of legal regulation of \\ economic activities of the \\ Financial University under the \\ Government of the Russian \\ Federation. \\ Oksana55@mail.ru
}

\author{
Vladislav Kudryashov Financial \\ University under the Government \\ of the Russian \\ FederationMoscow, Russia \\ candidate of historical sciences, \\ actual state 3 rd class counselor of \\ the Russian Federation, associate \\ professor of the Department of \\ legal regulation of economic \\ activities of the Financial \\ University under the Government \\ of the Russian Federation \\ kudryashov.minfin@ya.ru
}

\author{
Sergey Stepashkin Financial \\ University under the Government \\ of the Russian Federation \\ Moscow, Russia \\ candidate of pedagogical \\ sciences, associate professor of \\ the Department of legal \\ regulation of economic activities \\ of the Financial University under \\ the Government of the Russian \\ Federation. \\ sstepashkin@fa.ru
}

\begin{abstract}
The purpose of the scientific article is to analysis of foreign legal experience in providing medical and social expertise (on the example of the Republic of Belarus) to identify the specific features of the legal regulation of this institution. The authors examine the national legislation of the Republic of Belarus. It is noted that the basis of the legislation of the Republic of Belarus on disabled persons is the World Program of Action concerning Disabled Persons adopted by the United Nations and the Declaration on the Rights of Persons with Disabilities.

The authors disclose the activities of the medical and rehabilitation expert commission for recognizing the citizen as invalid, the formation of an individual rehabilitation program for disabled persons, consisting of three sections: the program of medical rehabilitation, vocational rehabilitation programs and employment and social rehabilitation program.
\end{abstract}

Keywords - health protection, medical and social expertise, disabled persons, rehabilitation, disability, life activity, legislation, individual rehabilitation program, legal regulation.

\section{INTRODUCTION}

The issues of legal regulation of medical and social expertise are traditionally considered in the framework of medical law, for example, Jackson, Emily[1], Brigit Toebes[2], Herring, Jonathan[3], Brazier, Margaret, Cave, Emma[4] and others. There are articles on rehabilitation of disabled people written by such authors as Ran $\mathrm{Yu}$ [5], $\mathrm{Lu} \mathrm{Yu}$, Qiang Li[6], Hui Ma, Yinhuan Chen[7], Alexander Yakoupov[8] и других.
The term "medical and social expertise" (examination of disability) means the examination of a citizen by a medical and rehabilitation expert commission (MREC) with the aim of:

1) determining the degree of disruption in the functions of human body's organs and systems, the degree of disability, the clinical and labour prognosis, the rehabilitation potential, and the acknowledgment of disability with the issuance of the MREC report in a form approved by the Ministry of Health;

2) determining the specific volumes, types and timing of rehabilitation activities and the formation of an individual rehabilitation program for a disabled person or a rehabilitation program for a victim of an accident at work or occupational disease, issuing a report for the agency of health care in the place of residence of a disabled person on the formation of an individual medical program rehabilitation.

\section{LEGISLATION OF THE REPUBLIC OF BELARUS ON DISABLED PERSONS: GENERAL DESCRIPTION}

As noted in the scientific literature, the United Nations World Program of Action concerning Disabled Persons and the Declaration on the Rights of Persons with Disabilities are the basis for the legislation of the Republic of Belarus on disabled persons[9].

On October 18, 2016 the Republic of Belarus ratified the Convention on the Rights of Persons with Disabilities, which aim is to promote, protect and ensure the full and equal enjoyment by all disabled persons of all human rights and 
fundamental freedoms, as well as to encourage respect for their inherent dignity.

In this regard, in order to ensure the creation of conditions and mechanisms for the implementation of the provisions of the Convention, was adopted a National action plan of implementation of the provisions of the Convention on the Rights of Persons with Disabilities for the period 20172025 in the Republic of Belarus[10].

The Constitution of the Republic of Belarus in Art. 45 guarantees citizens the right to health protection, including the right to free treatment in public health facilities, and also fixes legal guarantees in the field of social security, including the right to such security in the event of disability or loosing ability to work (Article 47 of the Constitution of the Republic of Belarus).

\section{ACTIVITIES OF MEDICAL AND REHABILITATION EXPERT COMMISSIONS}

According to Art. 32 of the Law of the Republic of Belarus of June 18, 1993 No. 2435-XII "On Health Care" (hereinafter - the Health Care Law of the RB)[11], medical and social expertise or examination of disability of patients is carried out among various types of medical examinations.

Regarding the legal regulation of public relations in the sphere of medical and social expertise, the Health Care Law of the RB determines a number of the following general provisions (Art. 34):

firstly, medical and rehabilitation expert commissions are given the authority to conduct medical and social expertise;

secondly, the report of the medical and rehabilitation expert commission on the conditions and nature of work prescribed to disabled persons is mandatory for employers;

thirdly, failure by employers to comply with the requirements of the medical and rehabilitation expert commission's report entails legal responsibility;

fourthly, the patient has the right to appeal the report of the medical and rehabilitation expert commission.

Within the framework of the organization of interdepartmental interaction, the Art. 5 of the Law of the Republic of Belarus of November 11, 1991 No. 1224-XII "On social protection of disabled persons in the Republic of Belarus" (hereinafter - the Law on the social protection of disabled persons of the RB) provides for the creation of a Republican interdepartmental council on the affairs of the disabled persons[12].

Specialists, representatives of committees, departments (divisions) for labour, employment and social protection of local executive and administrative bodies, insurance and other organizations may be involved in the work of medical and rehabilitation expert commissions with the right to deliberative voice.

Recognition of a citizen as a disabled person is carried out by a medical and rehabilitation expert commission when conducting a medical and social examination based on a comprehensive assessment of the health status of a citizen on the basis of clinical and functional, social, professional, labour and psychological data while using classifications of the main types of functional impairments and basic life criteria.

Depending on the severity of the disorder of the human body's functions and the limitations on life activity, the grouping and the cause of disability are determined for the persons recognized as disabled, and the category "disabled child" is acknowledged for persons under the age of 18 with the determination of the degree of loss of health.

Re-examination of a disabled person is carried out after the expiration of the terms of report of the medical and rehabilitation expert commission. In some cases the disability is acknowledged without specifying the period of reexamination.

In order to create a database of disabled persons, the medical and rehabilitation expert commissions records and analyzes the structure of disability and maintains A MREC disabled person registration card and A MREC disabled child registration card in forms approved by the Ministry of Health of the Republic of Belarus.

\section{LEGAL ISSUES OF REHABILITATION OF PERSONS WITH DISABILITIES}

An individual program for the rehabilitation of a disabled person is a document that defines a set of rehabilitation measures, specific types and terms of rehabilitation of a disabled person, as well as the persons responsible for carrying it out.

Individual rehabilitation program for a disabled person consists of three sections:

1) the program of medical rehabilitation;

2) the program of professional and labour rehabilitation;

3) the program of social rehabilitation.

The form of an individual rehabilitation program for a disabled person is approved by the Ministry of health of the Republic of Belarus in consultation with the Ministry of labour and social protection of the Republic of Belarus and the Ministry of education of the Republic of Belarus.

When drawing up an individual rehabilitation program for a disabled person, doctors of the medical and rehabilitation expert commission are required to inform the disabled person about his/her rights provided by law.

This program provides for a complex of rehabilitation measures, indicating their specific types and timing. Also, it is mandatory to indicate the persons responsible for carrying it out. At the same time, the legislation on health determines the procedure for the medical care of disabled persons (Art. 10 of the Law on the social protection of disabled persons of the RB).

Approved by the medical and rehabilitation expert commission, an individual program for the rehabilitation of a disabled person is of binding character.

At the same time, the full or partial refusal of the disabled person or his/her legal representative from the implementation of the program is the basis for the release of the relevant state authorities, as well as organizations and individual 
entrepreneurs rehabilitating disabled persons, from the implementation of the program.

\section{DISABILITY PREVENTION AND DEMOGRAPHIC SECURITY}

A special place in the system of sources of legal regulation is for the Law of the Republic of Belarus No. 422-3 of July 23, 2008 "On preventing disability and on rehabilitation of disabled persons" (hereinafter - the Law on the prevention of disability of the RB)[13].

Chapter 3 of this Law is devoted to the development and implementation of disability prevention and rehabilitation programs for disabled persons.

The main objectives of approving disability prevention programs include:

1) prevention of disability;

2) decrease in the frequency and severity of disability.

In turn, the approval of rehabilitation programs for disabled persons involves the achievement of the following objectives:

1) improving the quality of life of disabled persons;

2) social integration of disabled persons;

3) creation of an appropriate infrastructure (for example, the creation of a barrier-free living environment).

In accordance with Art. 12 of the Law on the prevention of disability of the RB there are distinguished state and local/territorial level programs for the prevention of disability and the rehabilitation of disabled persons. The approval of the former is attributed to the Council of Ministers of the Republic of Belarus, and the later one to the local councils of deputies.

At the same time, direct development of state programs is carried out by the republican government bodies and state organizations subordinate to the Government of the Republic of Belarus, at least once in five years.

Scientific organizations, institutions of higher education and public associations of disabled persons are also involved in the development of such programs. Further, on the basis of the state program approved by the Council of Ministers of the Republic of Belarus, local executive and administrative authorities conduct the development of territorial programs.

The main source of funding for these programs, according to Art. 15 of the Law on the prevention of disability of the RB, are the means of the republican and local budgets.

The state programs for the prevention of disability and rehabilitation of the disabled persons provides for the implementation of a number of activities, including: analysis of the causes of disability; development and implementation of industrial safety measures, prevention of accidents, ensuring environmental safety; creation of a rehabilitation system for disabled persons; development of a complex of measures for the adaptation of disabled persons, etc.

In particular, within the framework of the State program "People's health and demographic safety of the Republic of Belarus" for 2016-2020, it is provided the subprogram "Prevention and control of non-communicable diseases", one of the tasks of which is to reduce the level of premature mortality and to stabilize the level of disability of the people caused by the non-communicable diseases[14].

In its turn, the State program on social protection and employment promotion for 2016-2020 includes the subprograms "Prevention of disability and rehabilitation of disabled persons", "Barrier-free environment for disable and physically weakened persons", and "Social integration of disabled persons and elderly citizens"[15].

Thus, the norms on the accessibility of the physical environment for the life of disable persons are provided within the framework of state programs (subprograms) on creation of a barrier-free environment for the life of disable and physically weakened persons. It is noted that the number of buildings and constructions equipped with barrier-free environment elements is constantly increasing in the course of the implementation of relevant measures, so as the certain activity is being carried out to increase the number of social, domestic and other services accessible to disable persons[16].

The organization of vital activity of citizens, whose stay at home is impossible for a number of reasons, is provided by the institutions that run inpatient social services. In these institutions are developing new forms of services, including:

- short-term accommodation;

- stay in the offices of high comfort; disabilities.

- "social respite" for families raising children with

In order to assist disable persons in adapting to the independent living and work activities, the program documents provide for the establishment of compartments of accompanied residence.

Increasing competitiveness in the labour market and assisting in the implementation of labour rights implies the referral of disabled persons to labour rehabilitation and adaptation, as well as to vocational training and retraining. In addition, specialized jobs are reserved and created for the employment of disabled persons.

The Law of the Republic of Belarus on the prevention of disability defines the rehabilitation of disabled persons as a system of measures aimed at helping disabled persons to achieve their optimal physical, intellectual and social levels of activity, as well as their supporting through the provision of the necessary means, services, information and other ways of improving quality of their life and expanding the scope of their independence, which consists of medical, professional, labour and social rehabilitation

\section{CONCLUSIONS}

Thus, the medical and social expertise (MSI) (the examination of the disability of patients) is a field of science and a system of practical activities that functions in the public health system and, in accordance with the established procedure, determines the medical indications for social assistance and protection.

At the same time, MSI must also be defined as an independent field of scientific knowledge and a system of 
practical activities functioning at the junction of health, social insurance and social security. The social component provides for the integration of disable persons into the social micro- and macroenvironment. The preventive component is aimed at creating and improving preventive and rehabilitation technologies, reducing the risk of disabling diseases, preventing the onset of disability, reducing its severity and overcoming the limitation of life.

\section{REFERENCES}

[1] Jackson, Emily (2016) Medical law: text, cases, and materials. 4th ed., Oxford University Press, London, UK. ISBN 9780198743507 (In Press)

[2] Brigit Toebes. International health law: an emerging field of public international law //Indian Journal of International Law. - September 2015, Volume 55, Issue 3, pp 299-328. DOI https://doi.org/10.1007/s40901-016-0020-9

https://link.springer.com/article/10.1007/s40901-016-0020-9.

[3] Herring, Jonathan (2016) Medical law and ethics. Sixth edition. Oxford: Oxford University Press, 2016.

[4] Margaret Brazier and Emma Cave (2016) Medicine, patients and the law. Sixth edition. Manchester : Manchester University Press.

[5] Ran Yu Research on Teleworking of Urban Disabled Persons. International Conference on Contemporary Education, Social Sciences and Humanities (ICCESSH 2016). P. 567-570.

[6] Lu Yu, Qiang Li An Analysis of the Public Product Attribute: the Higher Education for the Disabled. 5th International Conference on Education, Management, Information and Medicine (EMIM 2015). P.1126-1129.

[7] Hui Ma, Yinhuan Chen Discussion on the Perfection of the Disabled Care System in China - From the Aspect of Protecting the Rights and Interests. Advances in Social Science, Education and Humanities Research (ASSEHR), volume 80. International Conference on Education, Culture and Social Development (ICECSD 2017). P.71-74.

[8] Alexander Yakoupov Art Rehabilitation of Disabled People in Russian Federation. International Conference on Education, Language, Art and Intercultural Communication (ICELAIC 2014). P.10-15.

[9] Bogdanovich L.N., Smychek V.B., Bogdanovich A.I. On the state policy of the Republic of Belarus in relation to the disabled persons // Health Organization, Hygiene and Epidemiology, №12, December 2015.
[10] National action plan for the implementation in the Republic of Belarus of the provisions of the Convention on the Rights of Persons with Disabilities for 2017-2025 (approved by the Decree of the Council of Ministers of the Republic of Belarus of June 13, 2017 No. 451)//Official website the Council of Ministers of the Republic of Belarus. URL: http://www.government.by/upload/docs/file6550643e5a4dcc7d.PDF (accessed Jun. 10, 2018).

[11] The Law of the Republic of Belarus of June 18, 1993 No. 2435-XII "On Health Care" // The National Legal Internet Portal of the Republic of Belarus. $\quad$ URL: http://www.pravo.by/document/?guid $=3871 \& \mathrm{p} 0=\mathrm{V} 19302435$ (accessed Jun. 10, 2018).

[12] The Law of the Republic of Belarus of November 11, 1991 No. 1224XII "On social protection of disabled persons in the Republic of Belarus"// The National Legal Internet Portal of the Republic of Belarus. URL: $\quad$ http://www.pravo.by/document/?guid=3871\&p0=v19101224 (accessed Jun. 10, 2018).

[13] The Law of the Republic of Belarus of July 23, 2008 No. 422-3 "On preventing disability and on rehabilitation of disabled persons"// National Register of Legal Acts of the Republic of Belarus of 04.08.2008, No. 184, art. 2/1519.

[14] State program "People's health and demographic security of the Republic of Belarus" for 2016-2020, (approved by the Decree of the Council of Ministers of the Republic of Belarus of March 14, 2016 No. 200) // The National Legal Internet Portal of the Republic of Belarus. URL: $\quad$ http://www.pravo.by/document/?guid $=3871 \& \mathrm{p} 0=\mathrm{C} 21600200$ (accessed Jun. 10, 2018).

[15] State program on social protection and employment promotion for 2016-2020 (approved by the Decree of the Council of Ministers of the Republic of Belarus of 30 January, 2016 №73// The National Legal Internet Portal of the Republic of Belarus. URL: http://www.pravo.by/document/?guid $=3871 \& \mathrm{p} 0=\mathrm{C} 21600073$ (accessed Jun. 10, 2018).

[16] National action plan for the implementation in the Republic of Belarus of the provisions of the Convention on the Rights of Persons with Disabilities for 2017-2025 (approved by the Decree of the Council of Ministers of the Republic of Belarus No. 451 of June 13, 2017) //Official website the Council of Ministers of the Republic of Belarus. URL: http://www.government.by/upload/docs/file6550643e5a4dcc7d.PDF (accessed Jun. 10, 2018) 